\title{
Addendum to: Development and Validation of a Scale to Measure Intimate Partner Violence Among Transgender and Gender Diverse Populations: Protocol for a Linear Three-Phase Study (Project Empower)
}

Rob Stephenson ${ }^{1 *}, \mathrm{MA}, \mathrm{MSc}, \mathrm{PhD}$; Kieran Todd ${ }^{2}, \mathrm{MPH}$; Kristi E Gamarel ${ }^{3}, \mathrm{PhD}$; Erin E Bonar ${ }^{2,4,5}$, PhD; Sarah Peitzmeier $^{1^{*}}, \mathrm{PhD}$

\footnotetext{
${ }^{1}$ Center for Sexuality and Health Disparities and The School of Nursing, University of Michigan, Ann Arbor, MI, United States

${ }^{2}$ Center for Sexuality and Health Disparities, University of Michigan, Ann Arbor, MI, United States

${ }^{3}$ Center for Sexuality and Health Disparities and The School of Public Health, University of Michigan, Ann Arbor, MI, United States

${ }^{4}$ Addiction Center, Department of Psychiatry, University of Michigan, Ann Arbor, MI, United States

${ }^{5}$ The Injury Prevention Center, University of Michigan, Ann Arbor, MI, United States

* these authors contributed equally
}

\section{Corresponding Author:}

Rob Stephenson, MA, MSc, PhD

Center for Sexuality and Health Disparities and The School of Nursing

University of Michigan

400 North Ingalls

Ann Arbor, MI, 48109

United States

Phone: 17346150149

Email: rbsteph@umich.edu

\section{Related Article:}

https://www.researchprotocols.org/2020/11/e23819/

(JMIR Res Protoc 2021;10(5):e28614) doi: 10.2196/28614

In "Development and Validation of a Scale to Measure Intimate Partner Violence Among Transgender and Gender Diverse Populations: Protocol for a Linear Three-Phase Study (Project Empower)" (JMIR Res Protoc 2020;9(11):e23819), corrections have been made to the authorship list and to the text of the paper to clarify the methods of the protocol.

Author Erin E Bonar has been added to the authorship list of the revised paper. The revised list of authors and affiliations is as follows:

Rob Stephenson ${ }^{1 *}, M A, M S c, P h D ;$ Kieran Todd ${ }^{2}$, MPH; Kristi E Gamarel ${ }^{3}$, PhD; Erin E Bonar ${ }^{2,4,5}$, PhD; Sarah Peitzmeier ${ }^{1 *}$, PhD

${ }^{1}$ Center for Sexuality and Health Disparities and The School of Nursing, University of Michigan, Ann Arbor, MI, United States

${ }^{2}$ Center for Sexuality and Health Disparities, University of Michigan, Ann Arbor, MI, United States

${ }^{3}$ Center for Sexuality and Health Disparities and The School of Public Health, University of Michigan, Ann Arbor, MI, United States

\author{
${ }^{4}$ Addiction Center, Department of Psychiatry, \\ University of Michigan, Ann Arbor, MI, United States \\ ${ }^{5}$ The Injury Prevention Center, University of \\ Michigan, Ann Arbor, MI, United States \\ *these authors contributed equally
}

To clarify the age of the participant group, mentions throughout the paper of participants as "aged over 15 years" have been changed to "aged 15 and above."

The section "Protection of Human Subjects" has been edited to clarify the risk management plan for participants.

References 40 and 45 in the original manuscript have been removed. 3 new references have been added to the reference list as References 41-43 and are cited in the "Health Outcomes" section. References have been renumbered accordingly. The full revised reference list appears below [1-86].

In the "Health Outcomes" section, the measure of suicidal ideation has been removed. The measure of substance abuse has been changed to the following:

Substance use measures will assess the use and frequency of use of alcohol and other drugs in the past 3 months and are based on prior work [41-44]. 
The correction will appear in the online version of the paper on the JMIR Publications website on May 12, 2021, together with the publication of this correction notice. Because this was made after submission to PubMed, PubMed Central, and other full-text repositories, the corrected article has also been resubmitted to those repositories.

\section{References}

1. Peitzmeier SM, Malik M, Kattari SK, Marrow E, Stephenson R, Agénor M, et al. Intimate Partner Violence in Transgender Populations: Systematic Review and Meta-analysis of Prevalence and Correlates. Am J Public Health 2020 Sep;110(9):e1-e14. [doi: 10.2105/ajph.2020.305774]

2. James S, Herman J, Rankin S, Keisling M, Mottet L, Anafi M. The Report of the 2015 U.S. Transgender Survey. Washington, DC: National Center for Transgender Equality; 2016.

3. Black M, Basile K, Breiding M, Smith S, Walters M, Merrick M, et al. The National Intimate Partner and Sexual Violence Survey (NISVS): 2010 Summary Report. Atlanta, GA: National Center for Injury Prevention and Control, Centers for Disease Control and Prevention; 2011.

4. Reisner SL, White Hughto JM, Gamarel KE, Keuroghlian AS, Mizock L, Pachankis JE. Discriminatory experiences associated with posttraumatic stress disorder symptoms among transgender adults. J Couns Psychol 2016 Oct;63(5):509-519 [FREE Full text] [doi: 10.1037/cou0000143] [Medline: 26866637]

5. White Hughto JM, Pachankis JE, Willie TC, Reisner SL. Victimization and depressive symptomology in transgender adults: The mediating role of avoidant coping. J Couns Psychol 2017 Jan;64(1):41-51 [FREE Full text] [doi: 10.1037/cou0000184] [Medline: 28068130]

6. Goldenberg T, Jadwin-Cakmak L, Harper GW. Intimate Partner Violence Among Transgender Youth: Associations with Intrapersonal and Structural Factors. Violence Gend 2018 Mar 01;5(1):19-25 [FREE Full text] [doi: 10.1089/vio.2017.0041] [Medline: 29588911]

7. Logie CH, Wang Y, Lacombe-Duncan A, Jones N, Ahmed U, Levermore K, et al. Factors associated with sex work involvement among transgender women in Jamaica: a cross-sectional study. Journal of the International AIDS Society 2017 Jan 01;20(1):21422. [doi: 10.7448/ias.20.01/21422]

8. Straus MA, Hamby SL, Boney-McCoy S, Sugarman DB. The Revised Conflict Tactics Scales (CTS2). Journal of Family Issues 2016 Jun 30;17(3):283-316. [doi: 10.1177/019251396017003001]

9. Munson M, Cook-Daniels L. Transgender/SOFFA: Domestic Violence/Sexual Assault Resource Sheet. Milwaukee, WI: FORGE; 2003.

10. Guadalupe-Diaz XL, Anthony AK. Discrediting Identity Work: Understandings of Intimate Partner Violence by Transgender Survivors. Deviant Behavior 2016 Jun 20;38(1):1-16. [doi: 10.1080/01639625.2016.1189757]

11. Woulfe JM, Goodman LA. Identity Abuse as a Tactic of Violence in LGBTQ Communities: Initial Validation of the Identity Abuse Measure. J Interpers Violence 2018 Mar 01:886260518760018. [doi: 10.1177/0886260518760018] [Medline: 29528799]

12. Peitzmeier SM, Hughto JM, Potter J, Deutsch MB, Reisner SL. Development of a Novel Tool to Assess Intimate Partner Violence Against Transgender Individuals. J Interpers Violence 2019 Jun 08;34(11):2376-2397. [doi: 10.1177/0886260519827660] [Medline: 30735080]

13. Peitzmeier S, Reisner S, Cooney E, Humes E, Wirtz A. Validation of a scale to measure transgender-specific psychological intimate partner violence. Cape Town, South Africa: Sexual Violence Research Initiative Forum; 2019.

14. Dyar C, Messinger AM, Newcomb ME, Byck GR, Dunlap P, Whitton SW. Development and Initial Validation of Three Culturally Sensitive Measures of Intimate Partner Violence for Sexual and Gender Minority Populations. J Interpers Violence 2019 May 05:886260519846856. [doi: 10.1177/0886260519846856] [Medline: 31057032]

15. Hendricks M, Testa R. A conceptual framework for clinical work with transgender and gender nonconforming clients: An adaptation of the Minority Stress Model. Professional Psychology: Research and Practice 2012 Oct;43(5):460-467. [doi: 10.1037/a0029597]

16. Sevelius JM. Gender Affirmation: A Framework for Conceptualizing Risk Behavior among Transgender Women of Color. Sex Roles 2013 Jun 01;68(11-12):675-689 [FREE Full text] [doi: 10.1007/s11199-012-0216-5] [Medline: 23729971]

17. Glynn TR, Gamarel KE, Kahler CW, Iwamoto M, Operario D, Nemoto T. The role of gender affirmation in psychological well-being among transgender women. Psychol Sex Orientat Gend Divers 2016 Sep;3(3):336-344 [FREE Full text] [doi: 10.1037/sgd0000171] [Medline: 27747257]

18. Gamarel KE, Reisner SL, Laurenceau J, Nemoto T, Operario D. Gender minority stress, mental health, and relationship quality: a dyadic investigation of transgender women and their cisgender male partners. J Fam Psychol 2014 Aug;28(4):437-447 [FREE Full text] [doi: 10.1037/a0037171] [Medline: 24932942]

19. Reisner SL, Gamarel KE, Nemoto T, Operario D. Dyadic effects of gender minority stressors in substance use behaviors among transgender women and their non-transgender male partners. Psychol Sex Orientat Gend Divers 2014 Mar;1(1):63-71 [FREE Full text] [doi: 10.1037/0000013] [Medline: 25642440]

20. Patton MQ. Qualitative Research \& Evaluation Methods. Thousand Oaks, CA: SAGE Publications; 1990. 
21. Dworkin S. Sample size policy for qualitative studies using in-depth interviews. Arch Sex Behav 2012 Dec;41(6):1319-1320. [doi: 10.1007/s10508-012-0016-6] [Medline: 22968493]

22. Beatty P, Willis G. Research Synthesis: The Practice of Cognitive Interviewing. Public Opinion Quarterly 2007 Jun 05;71(2):287-311. [doi: 10.1093/poq/nfm006]

23. Graham-Kevan N, Archer J. Intimate terrorism and common couple violence. A test of Johnson's predictions in four British samples. J Interpers Violence 2003 Nov 02;18(11):1247-1270. [doi: 10.1177/0886260503256656] [Medline: 19774764]

24. Testa R, Habarth J, Peta J, Balsam K, Bockting W. Development of the Gender Minority Stress and Resilience Measure. Psychology of Sexual Orientation and Gender Diversity 2015 Mar;2(1):65-77. [doi: 10.1037/sgd0000081]

25. Scheim AI, Bauer GR. The Intersectional Discrimination Index: Development and validation of measures of self-reported enacted and anticipated discrimination for intercategorical analysis. Soc Sci Med 2019 Apr;226:225-235 [FREE Full text] [doi: 10.1016/j.socscimed.2018.12.016] [Medline: 30674436]

26. Clark R, Coleman AP, Novak JD. Brief report: Initial psychometric properties of the everyday discrimination scale in black adolescents. J Adolesc 2004 Jun;27(3):363-368. [doi: 10.1016/j.adolescence.2003.09.004] [Medline: 15159094]

27. Forman TA, Williams DR, Jackson JS. Race, place, and discrimination. In: Gardner C, editor. Perspectives on Social Problems. Greenwich, CT: JAI Press; 1997:231-261.

28. Essed P. Analyzing Accounts of Racism. In: Understanding Everyday Racism: An Interdisciplinary Theory. Thousand Oaks, CA: SAGE Publications; 1991:119.

29. Brondolo E, Kelly KP, Coakley V, Gordon T, Thompson S, Levy E, et al. The Perceived Ethnic Discrimination Questionnaire: Development and Preliminary Validation of a Community Version1. J Appl Social Pyschol 2005 Feb;35(2):335-365. [doi: 10.1111/j.1559-1816.2005.tb02124.x]

30. Contrada RJ, Ashmore RD, Gary ML, Coups E, Egeth JD, Sewell A, et al. Measures of Ethnicity-Related Stress: Psychometric Properties, Ethnic Group Differences, and Associations With Well-Being1. J Appl Social Pyschol 2001 Sep;31(9):1775-1820. [doi: 10.1111/j.1559-1816.2001.tb00205.x]

31. Swim J, Cohen L, Hyers L. Experiencing everyday prejudice and discrimination. In: Prejudice: The Target's Perspective. San Diego, CA: Academic Press; 1998:37-60.

32. Piggott M. Double jeopardy: Lesbians and the legacy of multiple stigmatized identities. Swinburne University. 2004. URL: https://researchbank.swinburne.edu.au/file/4a7c253c-86df-4891-9420-8ac639834d5a/1/Margaret\%20Piggott\%20Thesis. pdf [accessed 2020-11-18]

33. Szymanski DM, Dunn TL, Ikizler AS. Multiple minority stressors and psychological distress among sexual minority women: The roles of rumination and maladaptive coping. Psychology of Sexual Orientation and Gender Diversity 2014 Dec;1(4):412-421. [doi: 10.1037/sgd0000066]

34. Sevelius J, Chakravarty D, Neilands TB, Keatley J, Shade SB, Johnson MO, HRSA SPNS Transgender Women of Color Study Group. Evidence for the Model of Gender Affirmation: The Role of Gender Affirmation and Healthcare Empowerment in Viral Suppression Among Transgender Women of Color Living with HIV. AIDS Behav 2019 May 29. [doi: 10.1007/s10461-019-02544-2] [Medline: 31144131]

35. Bockting WO, Miner MH, Swinburne Romine RE, Hamilton A, Coleman E. Stigma, Mental Health, and Resilience in an Online Sample of the US Transgender Population. Am J Public Health 2013 May;103(5):943-951. [doi: 10.2105/ajph.2013.301241]

36. Spanier GB. Measuring Dyadic Adjustment: New Scales for Assessing the Quality of Marriage and Similar Dyads. Journal of Marriage and the Family 1976 Feb;38(1):15. [doi: 10.2307/350547]

37. Tzeng OC. Family Relations. In: Measurement of Love and Intimate Relations: Theories, Scales, and Applications for Love Development, Maintenance, and Dissolution. Westport, CT: Praeger Publishers Inc; Jul 1994:349.

38. Sherman S, Gielen A, McDonnell K. Brief Report: Power and Attitudes in Relationships (PAIR) Among a Sample of Low-Income, African-American Women: Implications for HIV/AIDS Prevention. Sex Roles 2000;42:283-294. [doi: 10.1023/A:1007047424815]

39. Reisner S, Deutsch M, Cavanaugh T, Pardee D, White HJ, Peitzmeier S, et al. Best practices for obtaining a sexual health history with trans masculine individuals: Lessons learned from self-administered surveys and provider-collected clinical interview data. In: Proceedings of the 24th World Professional Association for Transgender Health Biennial Symposium: Growing Empowerment, Expertise, Evidence; WPATH'16. 2016 Presented at: 24th World Professional Association for Transgender Health Biennial Symposium: Growing Empowerment, Expertise, Evidence; June 18-21, 2016; Amsterdam, Netherlands.

40. Saunders J, Aasland O, Babor T, de la Fuente JR, Grant M. Development of the Alcohol Use Disorders Identification Test (AUDIT): WHO Collaborative Project on Early Detection of Persons with Harmful Alcohol Consumption--II. Addiction 1993 Jun;88(6):791-804. [doi: 10.1111/j.1360-0443.1993.tb02093.x] [Medline: 8329970]

41. NIDA. Alcohol, Smoking, and Substance Involvement Screening Test: NM-ASSIST. URL: https://www.drugabuse.gov/ sites/default/files/pdf/nmassist.pdf

42. WHO ASSIST Working Group. The Alcohol, Smoking and Substance Involvement Screening Test (ASSIST): development, reliability and feasibility. Addiction 2002 Sep;97(9):1183-1194. [doi: 10.1046/j.1360-0443.2002.00185.x] [Medline: 12199834] 
43. Grant BF, Chu A, Sigman R, Amsbary M, Kali J, Sugawara Y, et al. National Epidemiologic Survey on Alcohol and Related Conditions-III (NESARC- III): Source and Accuracy Statement. 2003. URL: https://www.niaaa.nih.gov/sites/default/files/ NESARC Final Report FINAL 18 15.pdf

44. Derogatis LR, Melisaratos N. The Brief Symptom Inventory: an introductory report. Psychol. Med 2009 Jul 09;13(3):595-605. [doi: $10.1017 / \mathrm{s} 0033291700048017]$

45. Ouimette P, Wade M, Prins A, Schohn M. Identifying PTSD in primary care: comparison of the Primary Care-PTSD screen (PC-PTSD) and the General Health Questionnaire-12 (GHQ). J Anxiety Disord 2008 Jan;22(2):337-343. [doi: 10.1016/j.janxdis.2007.02.010] [Medline: 17383853]

46. Primary Care PTSD Screen for DSM-5 (PC-PTSD-5). U.S. Department of Veterans Affairs. URL: http://www.ptsd.va.gov/ professional/assessment/screens/pc-ptsd.asp [accessed 2019-05-05]

47. Cella D, Riley W, Stone A, Rothrock N, Reeve B, Yount S, PROMIS Cooperative Group. The Patient-Reported Outcomes Measurement Information System (PROMIS) developed and tested its first wave of adult self-reported health outcome item banks: 2005-2008. J Clin Epidemiol 2010 Nov;63(11):1179-1194 [FREE Full text] [doi: 10.1016/j.jclinepi.2010.04.011] [Medline: 20685078]

48. Hegarty K, Bush R, Sheehan M. The Composite Abuse Scale: Further Development and Assessment of Reliability and Validity of a Multidimensional Partner Abuse Measure in Clinical Settings. Violence 2005 Oct 01;20(5):529-547. [doi: 10.1891/vivi.2005.20.5.529]

49. Tabachnick B, Fidell L. Using multivariate statistics. Boston, MA: Allyn \& Bacon/Pearson Education; 2007.

50. Cudeck R. Exploratory factor analysis. In: Tinsley H, Brown S, editors. Handbook of Applied Multivariate Statistics and Mathematical Modeling. Cambridge, MA: Academic Press; 2000.

51. Hinkin TR. A Brief Tutorial on the Development of Measures for Use in Survey Questionnaires. Organizational Research Methods 2016 Jun 29;1(1):104-121. [doi: 10.1177/109442819800100106]

52. DeVellis R. Scale development: Theory and applications. Thousand Oaks, CA: SAGE Publications; 2017.

53. Yu CY, Muthen BO. Evaluation of model fit indices for latent variable models with categorical and continuous outcomes. 2002 Presented at: Annual Conference of the American Educational Research Association; April 4, 2002; New Orleans, Louisiana.

54. Schumacker R, Lomax R. A Beginner's Guide to Structural Equation Modeling. Mahwah, NJ: Lawrence Erbaum Associates; 2004.

55. Snijders T, Bosker R. Multilevel analysis: An introduction to basic and applied multilevel analysis. In: Multilevel Analysis. Thousand Oaks, CA: SAGE Publications; 1999.

56. Durwood L, McLaughlin KA, Olson KR. Mental Health and Self-Worth in Socially Transitioned Transgender Youth. J Am Acad Child Adolesc Psychiatry 2017 Feb;56(2):116-123.e2 [FREE Full text] [doi: 10.1016/j.jaac.2016.10.016] [Medline: 28117057]

57. Valentine SE, Peitzmeier SM, King DS, O'Cleirigh C, Marquez SM, Presley C, et al. Disparities in Exposure to Intimate Partner Violence Among Transgender/Gender Nonconforming and Sexual Minority Primary Care Patients. LGBT Health 2017 Aug;4(4):260-267. [doi: 10.1089/lgbt.2016.0113] [Medline: 28719246]

58. Seelman KL, Colón-Diaz MJ, LeCroix RH, Xavier-Brier M, Kattari L. Transgender Noninclusive Healthcare and Delaying Care Because of Fear: Connections to General Health and Mental Health Among Transgender Adults. Transgend Health 2017 Dec;2(1):17-28 [FREE Full text] [doi: 10.1089/trgh.2016.0024] [Medline: 28861545]

59. Bockting W, Coleman E, Deutsch MB, Guillamon A, Meyer I, Meyer W, et al. Adult development and quality of life of transgender and gender nonconforming people. Current Opinion in Endocrinology \& Diabetes and Obesity 2016;23(2):188-197. [doi: 10.1097/med.0000000000000232]

60. HIV and Transgender People. Centers for Disease Control and Prevention. 2017. URL: https://www.cdc.gov/hiv/group/ gender/transgender/index.html [accessed 2019-05-05]

61. Gamarel KE, Reisner SL, Laurenceau J, Nemoto T, Operario D. Gender minority stress, mental health, and relationship quality: a dyadic investigation of transgender women and their cisgender male partners. J Fam Psychol 2014 Aug;28(4):437-447 [FREE Full text] [doi: 10.1037/a0037171] [Medline: 24932942]

62. Meyer IH, Brown TN, Herman JL, Reisner SL, Bockting WO. Demographic Characteristics and Health Status of Transgender Adults in Select US Regions: Behavioral Risk Factor Surveillance System, 2014. Am J Public Health 2017 Apr;107(4):582-589. [doi: 10.2105/ajph.2016.303648]

63. Reisner SL, Gamarel KE, Dunham E, Hopwood R, Hwahng S. Female-to-male transmasculine adult health: a mixed-methods community-based needs assessment. J Am Psychiatr Nurses Assoc 2013 Aug 20;19(5):293-303. [doi: 10.1177/1078390313500693] [Medline: 23963876]

64. Reisner SL, Greytak EA, Parsons JT, Ybarra ML. Gender minority social stress in adolescence: disparities in adolescent bullying and substance use by gender identity. J Sex Res 2015 Apr 17;52(3):243-256 [FREE Full text] [doi: 10.1080/00224499.2014.886321] [Medline: 24742006]

65. Reisner SL, Katz-Wise SL, Gordon AR, Corliss HL, Austin SB. Social Epidemiology of Depression and Anxiety by Gender Identity. J Adolesc Health 2016 Aug;59(2):203-208 [FREE Full text] [doi: 10.1016/j.jadohealth.2016.04.006] [Medline: 27267142] 
66. Stephenson R, Riley E, Rogers E, Suarez N, Metheny N, Senda J, et al. The Sexual Health of Transgender Men: A Scoping Review. J Sex Res 2017 Jan 31;54(4-5):424-445. [doi: 10.1080/00224499.2016.1271863] [Medline: 28140660]

67. Reisner SL, White JM, Mayer KH, Mimiaga MJ. Sexual risk behaviors and psychosocial health concerns of female-to-male transgender men screening for STDs at an urban community health center. AIDS Care 2014 Nov 09;26(7):857-864 [FREE Full text] [doi: 10.1080/09540121.2013.855701] [Medline: 24206043]

68. Grant J, Mottet L, Tanis J, Harrison J, Herman J, Keisling M. Injustice at Every Turn: A Report of the National Transgender Discrimination Survey. National Center for Transgender Equality. 2011. URL: https://ransequality.org/sites/default/files/ docs/resources/NTDS Exec Summary.pdf [accessed 2019-05-05]

69. Bockting WO, Miner MH, Swinburne Romine RE, Hamilton A, Coleman E. Stigma, Mental Health, and Resilience in an Online Sample of the US Transgender Population. Am J Public Health 2013 May;103(5):943-951. [doi: 10.2105/ajph.2013.301241]

70. Budge SL, Adelson JL, Howard KAS. Anxiety and depression in transgender individuals: the roles of transition status, loss, social support, and coping. J Consult Clin Psychol 2013 Jun;81(3):545-557. [doi: 10.1037/a0031774] [Medline: 23398495]

71. Hoffman B. An Overview of Depression among Transgender Women. Depress Res Treat 2014;2014:394283-394289 [FREE Full text] [doi: 10.1155/2014/394283] [Medline: 24744918]

72. Igartua KJ, Gill K, Montoro R. Internalized homophobia: a factor in depression, anxiety, and suicide in the gay and lesbian population. Can J Commun Ment Health 2003 Sep;22(2):15-30 [FREE Full text] [doi: 10.7870/cjcmh-2003-0011] [Medline: 15868835]

73. Nahata L, Quinn GP, Caltabellotta NM, Tishelman AC. Mental Health Concerns and Insurance Denials Among Transgender Adolescents. LGBT Health 2017 Jun;4(3):188-193. [doi: 10.1089/lgbt.2016.0151] [Medline: 28402749]

74. Nuttbrock L, Bockting W, Rosenblum A, Hwahng S, Mason M, Macri M, et al. Gender Abuse and Major Depression Among Transgender Women: A Prospective Study of Vulnerability and Resilience. Am J Public Health 2014 Nov;104(11):2191-2198. [doi: 10.2105/ajph.2013.301545]

75. Clements-Nolle K, Marx R, Katz M. Attempted Suicide Among Transgender Persons. Journal of Homosexuality 2006 Oct 11;51(3):53-69. [doi: 10.1300/j082v51n03 04]

76. Mereish EH, O'Cleirigh C, Bradford JB. Interrelationships between LGBT-based victimization, suicide, and substance use problems in a diverse sample of sexual and gender minorities. Psychol Health Med 2014 Mar 27;19(1):1-13 [FREE Full text] [doi: 10.1080/13548506.2013.780129] [Medline: 23535038]

77. Mustanski B, Liu RT. A longitudinal study of predictors of suicide attempts among lesbian, gay, bisexual, and transgender youth. Arch Sex Behav 2013 Apr 5;42(3):437-448. [doi: 10.1007/s10508-012-0013-9] [Medline: 23054258]

78. Reisner SL, Vetters R, Leclerc M, Zaslow S, Wolfrum S, Shumer D, et al. Mental health of transgender youth in care at an adolescent urban community health center: a matched retrospective cohort study. J Adolesc Health 2015 Mar;56(3):274-279 [FREE Full text] [doi: 10.1016/j.jadohealth.2014.10.264] [Medline: 25577670]

79. Operario D, Nemoto T. HIV in transgender communities: syndemic dynamics and a need for multicomponent interventions. J Acquir Immune Defic Syndr 2010 Dec;55 Suppl 2:S91-S93 [FREE Full text] [doi: 10.1097/QAI.0b013e3181fbc9ec] [Medline: 21406995]

80. Baral SD, Poteat T, Strömdahl S, Wirtz AL, Guadamuz TE, Beyrer C. Worldwide burden of HIV in transgender women: a systematic review and meta-analysis. The Lancet Infectious Diseases 2013 Mar;13(3):214-222. [doi: 10.1016/s1473-3099(12)70315-8]

81. Melendez RM, Pinto R. 'It's really a hard life': love, gender and HIV risk among male-to-female transgender persons. Cult Health Sex 2007 May;9(3):233-245 [FREE Full text] [doi: 10.1080/13691050601065909] [Medline: 17457728]

82. Reisner SL, Pardo ST, Gamarel KE, White Hughto JM, Pardee DJ, Keo-Meier CL. Substance Use to Cope with Stigma in Healthcare Among U.S. Female-to-Male Trans Masculine Adults. LGBT Health 2015 Dec;2(4):324-332 [FREE Full text] [doi: 10.1089/lgbt.2015.0001] [Medline: 26788773]

83. Elamin M, Garcia M, Murad M, Erwin P, Montori V. Effect of sex steroid use on cardiovascular risk in transsexual individuals: a systematic review and meta-analyses. Clin Endocrinol (Oxf) 2010 Jan;72(1):1-10. [doi: 10.1111/j.1365-2265.2009.03632.x] [Medline: 19473174]

84. Wierckx K, Elaut E, Declercq E, Heylens G, De Cuypere G, Taes Y, et al. Prevalence of cardiovascular disease and cancer during cross-sex hormone therapy in a large cohort of trans persons: a case-control study. Eur J Endocrinol 2013 Oct;169(4):471-478. [doi: 10.1530/EJE-13-0493] [Medline: 23904280]

85. Feldman J, Brown GR, Deutsch MB, Hembree W, Meyer W, Meyer-Bahlburg HF, et al. Priorities for transgender medical and healthcare research. Current Opinion in Endocrinology \& Diabetes and Obesity 2016;23(2):180-187. [doi: $10.1097 / \mathrm{med} .0000000000000231]$

86. Stephenson R, Finneran C. The IPV-GBM scale: a new scale to measure intimate partner violence among gay and bisexual men. PLoS One 2013 Jun 5;8(6):e62592 [FREE Full text] [doi: 10.1371/journal.pone.0062592] [Medline: 23755098] 
This is a non-peer-reviewed article. Submitted 08.03.21; accepted 07.04.21; published 12.05.21.

Please cite as:

Stephenson R, Todd K, Gamarel KE, Bonar EE, Peitzmeier S

Addendum to: Development and Validation of a Scale to Measure Intimate Partner Violence Among Transgender and Gender Diverse

Populations: Protocol for a Linear Three-Phase Study (Project Empower)

JMIR Res Protoc 2021;10(5):e28614

URL: https://www.researchprotocols.org/2021/5/e28614

doi: $10.2196 / 28614$

PMID: $\underline{33979298}$

CRob Stephenson, Kieran Todd, Kristi E Gamarel, Erin E Bonar, Sarah Peitzmeier. Originally published in JMIR Research Protocols (https://www.researchprotocols.org), 12.05.2021. This is an open-access article distributed under the terms of the Creative Commons Attribution License (https://creativecommons.org/licenses/by/4.0/), which permits unrestricted use, distribution, and reproduction in any medium, provided the original work, first published in JMIR Research Protocols, is properly cited. The complete bibliographic information, a link to the original publication on http://www.researchprotocols.org, as well as this copyright and license information must be included. 